$$
\begin{aligned}
& \text { بررسى فحاليت آنزيمهاى آنتى اكسيدان راش شرقى نسبت به تغيير ات محيطى در طول }
\end{aligned}
$$

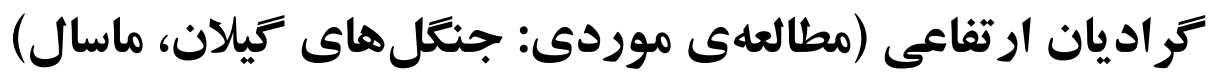

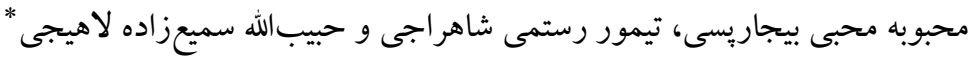

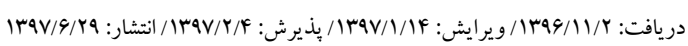

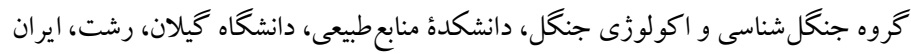

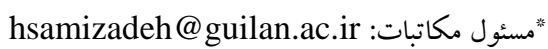

$$
\begin{aligned}
& \text { جكيده. بهنظور درك سازو كار ساز كارى اكوفيزيولوزى راششرقى Fagus orientalis Lipsky نسبت به تغييرات ارتفاعى، ميزان فعاليت آنزيمهاى آنتى- }
\end{aligned}
$$

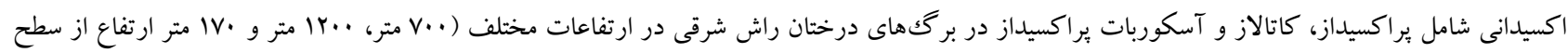

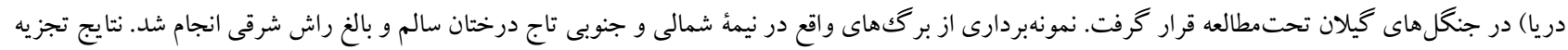

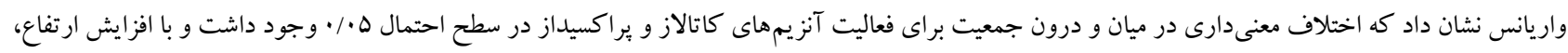

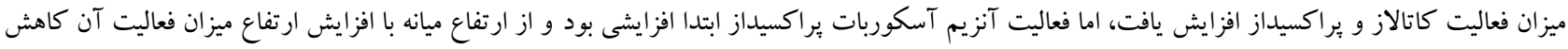

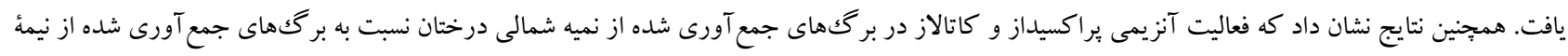

$$
\begin{aligned}
& \text { جنوبى درختان بيشتر بود. } \\
& \text { وازههاى كليدى. اكسيزن فعال، ايران، تغييرات اقليم، ساز گارى، شاخص هاى اكوفيز يولوزى بونى }
\end{aligned}
$$

\title{
Study of antioxidant enzymes activity of Fagus orientalis Lipsky to environmental changes along altitude gradient (case study: Guilan forests, Masal)
}

\author{
Mahboobe Mohebi Bijarpasi, Teymuor Rostami Shahraji \& Habiboala Samizadeh Lahiji* \\ Received 22.01.2018/ Revised 03.04.2018/ Accepted 24.04.2018/ Published 20.09.2018
}

Department of Silvicultural and Forest Ecology, Faculty of Natural Resources, University of Guilan, Rasht, Iran Correspondent author: hsamizadeh@guilan.ac.ir

\begin{abstract}
To understand the Eco physiological adaptation mechanisms of Fagus orientalis Lipsky to altitude changes, the activities of Peroxidase (POD), Catalase (CAT), and Ascorbate peroxidase (APX) in leaves of Fagus orientalis in different altitudes (A1: $700 \mathrm{~m}$, A2: $1200 \mathrm{~m}$, A3: $1700 \mathrm{~m}$ above sea level) was studied in the forests of Guilan. Samples of leaves were collected from southern and northern parts of the crown of healthy and mature trees. The results of analysis variance showed that there was a significant difference between and within the population for the activity of catalase and peroxidase enzymes at the probability level of 0.05 . With the increase of altitude, the activity of catalase and peroxidase increased but the activity of Ascorbate peroxidase enzyme initially increased and subsequently decreased as the elevation went higher from the middle altitude. Also, the results showed that the enzymatic activity of peroxidase and catalase in the leaves gathered from the tree-crown of the northern part was more than those of the southern part.
\end{abstract}

Keywords. adaptability, climate change, Iran, physicoecological indices, reactive oxygen 
2011; Espahbodi, 2005) فر ايندهاى ياختهاى مانند متابوليسم اكسين، تشكيل جوب، اتصالات

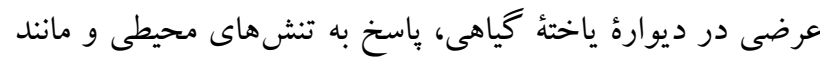

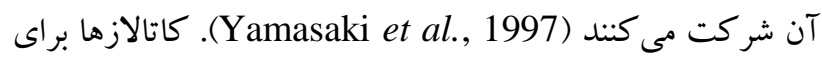

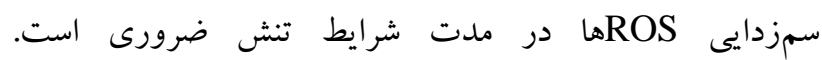

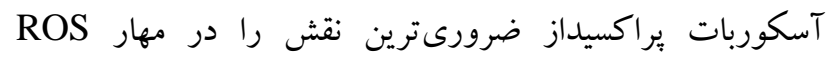

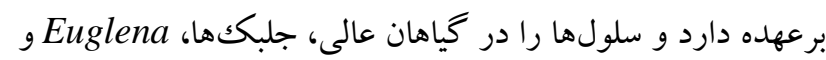

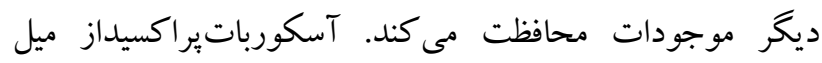

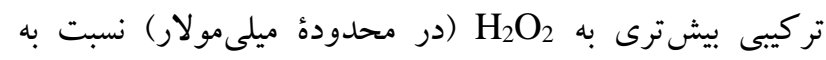

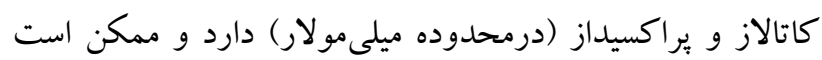

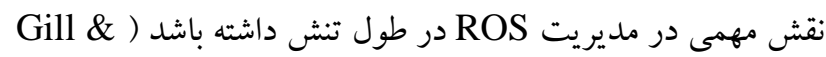
Ghua .Tuteja, 2010 Calligonum بيوشيميايى و فيزيولوزيكى روى كونه roborovskii يارامترهاى اندازه گيرىشده در ارتفاعات مختلف متغير است و و

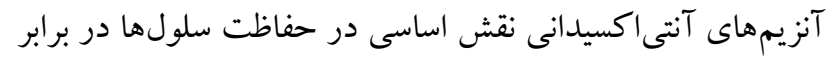
محصولات اكسيزن فعال ايفا مى كنند. Babaei و همكاران

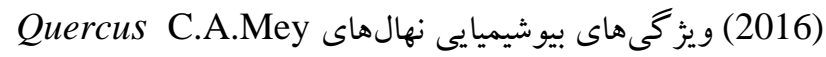
castaneifolia

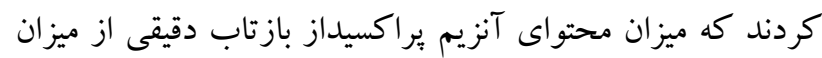
نور دريافتى در ارتفاعات مختلف را نشان مىدهد. Lykholat و

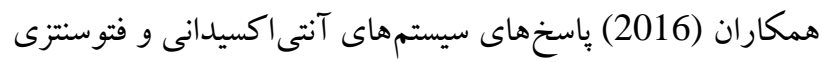
Fraxinus و Quercus robur L. برگك درختان گونهاى رادنل excelsior L.

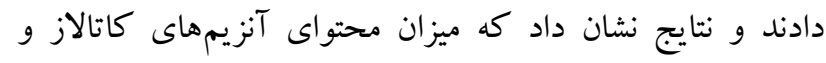

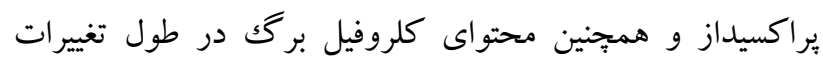

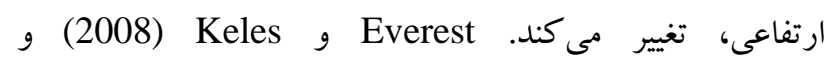
Zolfaghari داشتند كه سطوح بالاترى از تركيبات آنتىاكسيدانى و محتواى نهاي

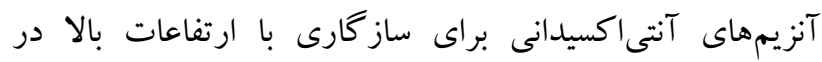

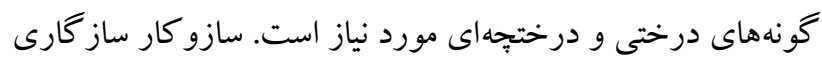

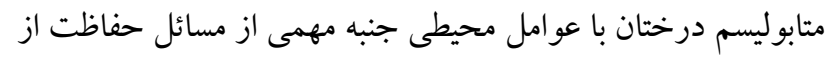
جنگل است. اين موضوع در سالهاى اخير به شدت تحتمطالعه

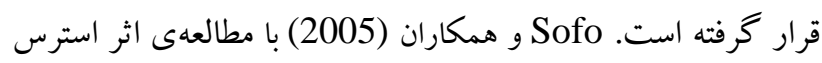
خشكى بر فعالبت آنتى اكسيدانى آنزيمهاى سوير اكسيد ديسمو تاز،

\section{مقدمه}

همراه با افزايش ارتفاع عوامل محيطى ازجمله دما، رطوبت، فشار هوا و ميزان تابش نور خورشيد تغيير مى كند. همراه با تغييرات عوامل محيطى، تغيير در ساختار و فيزيولوزى كياهان در طول كراديان ارتفاعى مشاهده شده است. در ارتفاعات بالاتر نسبت به ارتفاعات يايينتر گياهان در معرض تابش بيشتر، نوسانات دمايى زياد، سرعت باد بيشتر، و همجنين فشار جزيى كازهاو و محدوديت آب و مواد مغذى قرار مى گيرند و اين ممكن است ياسخهاى ريختشناسى و فيزيولوزيكى درختان را تحت تاثير قرار دهد (Karner, 1998). تركيبات استرسزاى زيستمحيطى (درجه حرارت يايين، شدت نور و خشكى) در ارتفاعات بالا مىتواند باعث افزايش توليد كونهاى اكسيزّن فعال شود كه محتواى زياد و سمى آن به تخريب بروتئينها، جربىها، كربوهيدراتها و DNA و سرانجام به مرگك سلولى منجر مى شود كه نتيجه تنش اكسيداتيو است (Gill \& Tuteja, 2010). تمام گياهان براى زندهماندن بايد با استرس اكسيداتيو روبرو شوند و از استراتزىهاى دفاعى مختلفى براى كاهش اثرات مضر توليدات اكسيزن فعال (ROS) استفاده كنند. كاهش و يا افزايش فعاليتهاى آنزيمى، يكى از راههاى مقابله و يا تحمل تنشها است. همراه با تغييرات تدريجى ارتفاع، كياه خود را با اين تغييرات ساز گار مى كند. ساز گارى مىتواند با تغيير در محتواى بسيارى از متابوليتها و نيز آنزيمهايى مثل براكسيداز، كاتالاز و آسكوربات براكسيداز باشد. گونههاى اكسيزٔن فعال، با آنزيمهاى آنتى اكسيدانى ماند كاتالاز و يراكسيداز و همجنين با مولكولهاى آنتى اكسيدانى مانند آسكوربات خنثى و غيرفعال مىشوند. از آنجايى كه ظرفيت و يُاسخ سيستمهاى آنتى اكسيدانى به توانايى گياهان براى مقاومت در برابر استرسهاى اكسيداتيو كمكك مى كند، تحقيق درباره اقدامات حفاظتى بهويثه دربارهُ نوسانات شرايط محيطى در گونهاى درختان مورد توجه قرار كرفته است (Polle, 1996). طبق مطالعات انجامشده، آنزيمهايى همجون براكسيداز، كاتالاز، سويراكسيدديسموتاز در تعداد زيادى از كونههاى جنگلى مثل بارانك،، صنوبر، راش، افرا، بلوط، سدر و نظاير اينها با هدف هاى مختلفى همجِون بررسى تنوع، انتخاب يايهها يا اكوتيبٍهاى مقاوم به تنش در درون يا ميان

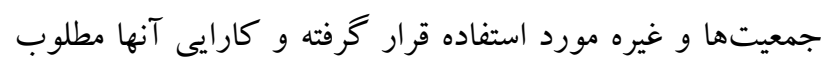
ارزيابى شده است (Babaei et al., 2012; Raeisi et al., 
از جمع آورى در نيتروزن مايع ذخيره شده و به آزمايشگاه منتقل و در دماى ·^- نغهلدارى شد.

بروسى آنزيمها در اين مطالعه فعاليت آنزيمهاى يراكسيداز، آسكوربات-

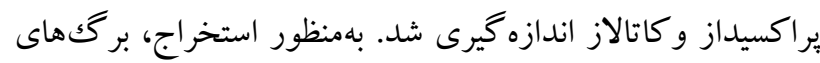

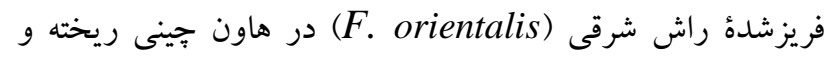

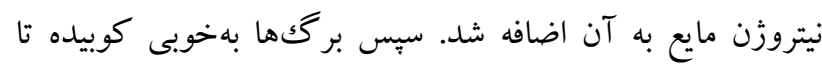

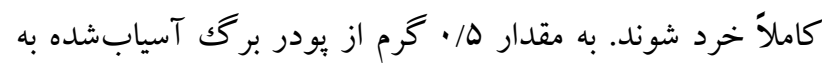

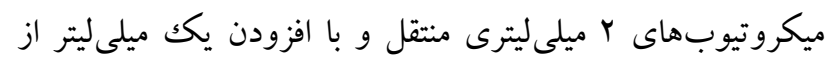

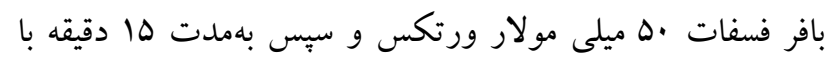

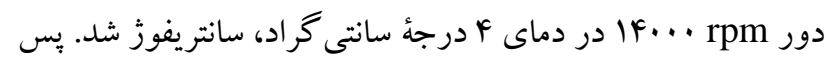

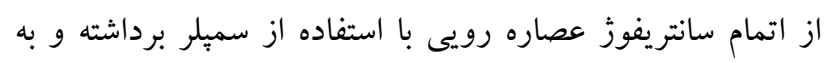

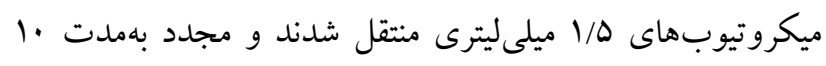

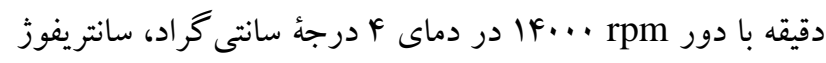

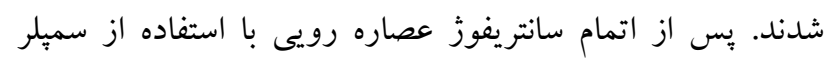

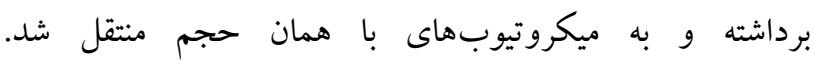
ميكروتيوبهاى حاوى عصاره در زمان سايش بر كُها و سانتريفوز

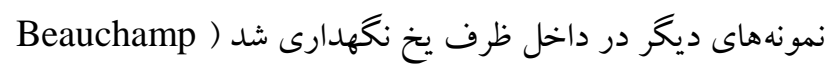
آن Fridovich, 1971

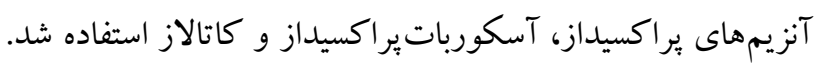

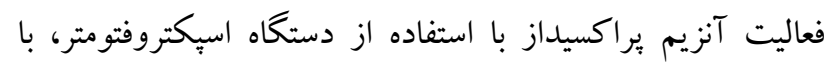

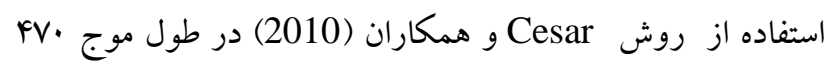
نانومتر بهمدت Y دقيقه تحت سنجش قرار كرفت. محتواى آنزيم

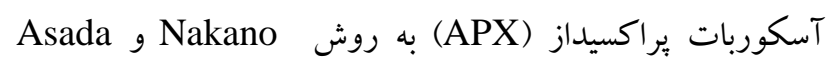

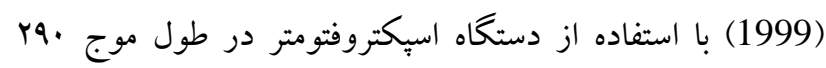

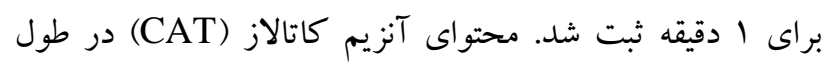

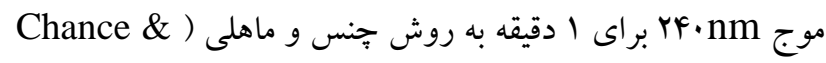
Kolmogorov-Sm- انجام شد. از آزمون جنس و ماهلى (Maehly, 1955

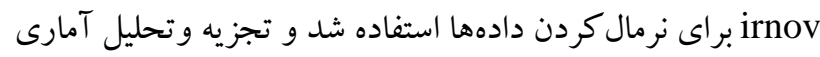
دادهها در قالب يكك طرح آمارى آشيانهاى (Nested ANOVA) با استفاده از رويه GLM نرمافزار تعيين شاخص بِاستيسيتى فيزيولوزيكى شاخص بلاستيسيتى فيزيولوزيكى با استفاده از فرمول زير محاسبه بلهيه

شد (Qipeng et al., 2008):

$$
\mathrm{PPI}=\frac{\mathrm{Xmax}-\mathrm{Xmin}}{\mathrm{Xmax}}
$$

كاتالاز، براكسيداز و آسكوربات بِراكسيداز درختان زيتون نشان دادند كه با افزايش شدت خشكى ميزان فعاليت آنزيمهاى سوير اكسيد ديسمو تاز، آسكوربات بِراكسيداز، كاتالاز و يُراكسيداز

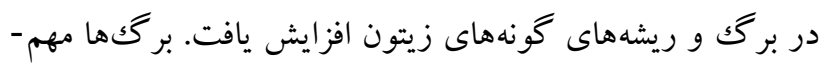

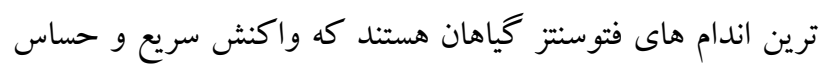
نسبت به تغييرات محيطى از خود نشان مىدهند. بنابراين، ياسخ

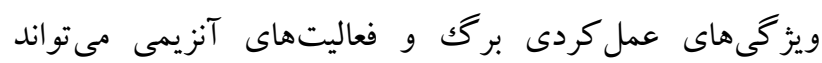

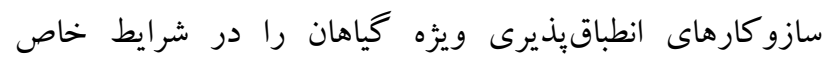

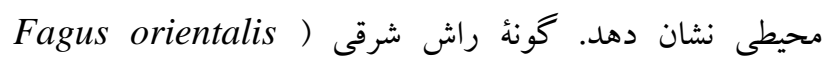
(Lipsky

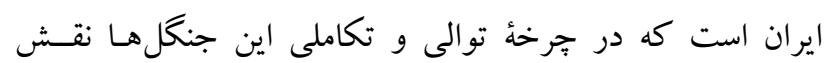

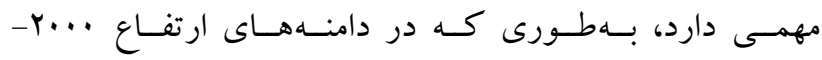

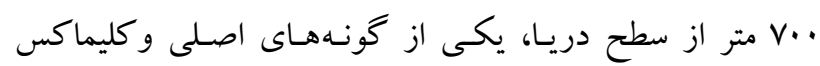

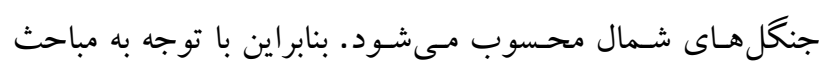

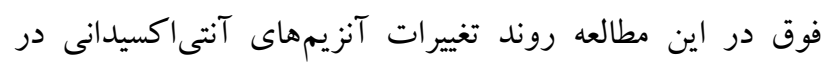

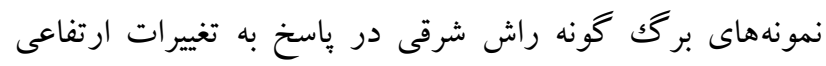
بروسى شد.

\section{مواد و روشها}

براى انجام اين تحقيق سه رويشگاه درختان راش در طول يك

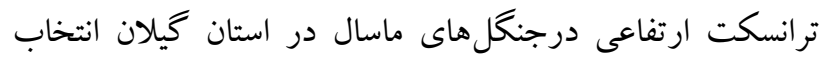

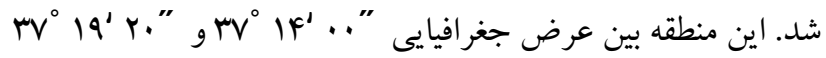

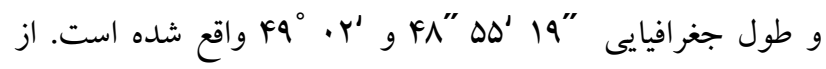
آنجايى كه هدف از اين تحقيق بررسى تغييرات بيوشيميايى در

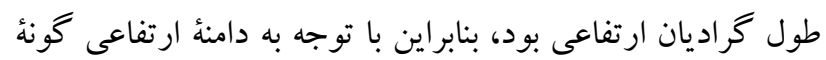

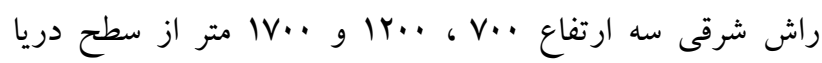

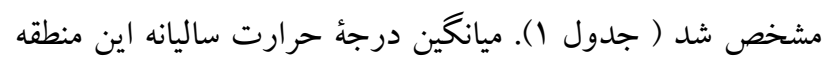

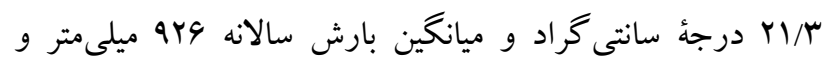

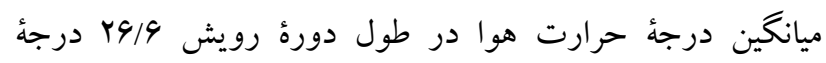

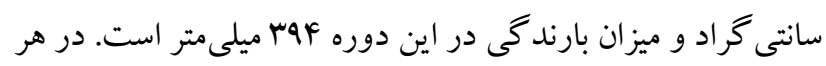

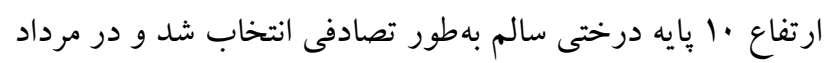

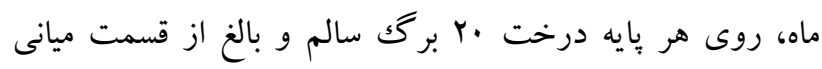

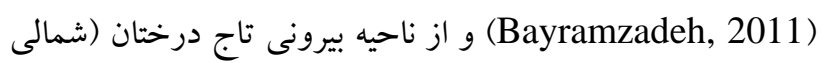
و جنوبى) جمع آورى شد (Hatziskakis et al., 2011).

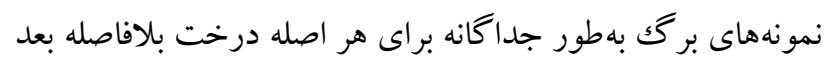


جدول 1- مشخصات منطقه تحتمطالعه.

Table 1. Specifications of the study areas.

\begin{tabular}{|c|c|c|c|c|}
\hline جهت & شيب (\%) & عرض جغرافيايى & طول جغرافيايى & رتفاع از سطح دريا (متر) \\
\hline شمال - شمال شرقى & $r \Delta-r$. & $r \wedge^{\circ} \Delta F^{\prime}$ & $r v^{\circ} 1 q^{\prime} r .^{\prime \prime}$ & (يايين) V.. \\
\hline شرقى - جنوب شرقى & $r \Delta-F$. & $r \wedge^{\circ} \Delta v^{\prime}$ & $r v^{\circ} \mid v^{\prime} F_{.}$. & 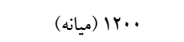 \\
\hline شمال - شمال شرقى & 9.-90 & $\mu \Lambda^{\circ} \Delta \Lambda^{\prime} r . "$ & $r v^{\circ} 1 \Lambda^{\prime} q . "$ & l(بلا) IV.. \\
\hline
\end{tabular}

جدول r - تغييرات ميزان فعاليت آنزيمهاى تحت مطالعة بركى درختان راش شرقى در جهت هاى شمالى و جنوبى تاج درختان در طول تغييرات ارتفاعى. Table 2. Changes in the activity of the enzymes studied in the beech leaves in northern and southern axes of the tree crown along different altitudinal gradient.

\begin{tabular}{|c|c|c|c|c|}
\hline \multicolumn{3}{|c|}{ لمارتفاع از سطح دريا } & \multirow{2}{*}{ جهت جغرافيايى } & \multirow{2}{*}{ آنزيم } \\
\hline $\mathrm{lv} \cdot \mathrm{m}$ a.s.l. & $r \cdot \cdot m$ a.s.l. & v $\cdot \mathrm{m}$ a.s.l. & & \\
\hline$\cdot / r_{\Lambda \pm} \cdot / \cdots \wedge$. & $. / .4 \pm \pm / . .19$ & $\cdot / \sim r q \pm * / \ldots r q$ & شمالى ل مالى & \multirow{2}{*}{ ير براكسيداز } \\
\hline$\cdot / 19 \pm . / . \Delta r$ & $\cdot / \cdot v \pm . / . \cdot 18$ & $\cdot \cdot \cdot \curlyvee \wedge \pm \cdot / \cdots \| \uparrow$ & جنوبى ل جنى & \\
\hline$. / 11 \pm \cdot / . \cdot \psi \Delta$ & $. / .9 \mathrm{~V} \pm . / . r q$ & $\cdot / . r \pm \pm \cdot \cdots r$ & شمالى ل كالى & \multirow{2}{*}{ كاتلاز } \\
\hline$\cdot / \cdot \vee \vee \perp \pm \cdot / \cdot \cdot \varphi q$ & $. / .91 \pm . / .019$ & $\cdot / . r \pm * / \cdots 1$ & جنوبى لجي ل جن & \\
\hline 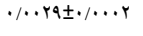 & $\cdot / . r r \pm \pm / \ldots r$ & $\cdot / \cdot r+ \pm . / \ldots r$ & شمالى لم كلى & \multirow{2}{*}{ آسكوربات يراكسيداز } \\
\hline$\% \cdot r \mathrm{rV} \pm / \cdots r$ & $\cdot / \cdot r v \pm \cdot / \ldots r$ & $\cdot / \cdot \cdot r \cdot \pm \cdot / \cdots+1$ & جنوبى لجي & \\
\hline
\end{tabular}

$$
\text { جدول r- نتايج تحليل واريانس با طرح آشيانهاى فعاليت آنزيمى در طول تغييرات ارتفاعى. }
$$

Table 3. Results of nested crossed analysis of variance for enzyme activity along different altitudinal gradient.

\begin{tabular}{|c|c|c|c|c|}
\hline \multicolumn{3}{|c|}{ ميانكين مربعات } & \multirow[t]{2}{*}{ درجه آزادى } & \multirow[t]{2}{*}{ منبع تغييرات } \\
\hline آسكوربات يراكسيداز & كاتالاز & يراكسيداز & & \\
\hline $1 / 9 \cdot \lambda^{\text {ns }}$ & $\%$ & $\% \ldots F^{\circ}$ & $r$ & جمعيت \\
\hline$f / 19 \mathrm{~V}^{n s}$ & $r / 9 A r^{\circ}$ & $\cdot / \cdot 1^{*}$ & 1 & جهت \\
\hline $1 / \mathrm{rV} \Delta^{\mathrm{ns}}$ & $\Delta / F / 9^{\circ}$ & $\cdot / \cdot \cdot 1^{*}$ & $r$ & جمعيت × جهت \\
\hline$\Delta / . . r$ & $\% . r$ & .1 .99 & & خطا \\
\hline$r q / F$. & $M / \Delta Q$ & $\Delta r / \uparrow A$ & & ضريب تغييرات \\
\hline
\end{tabular}

جنوبى تاج درخت بود (جدول Y، شكل ب). فعاليت آنزيم آسكوربات يراكسيداز در نيمهُ شمالى تاج درختان همراه با افزايش

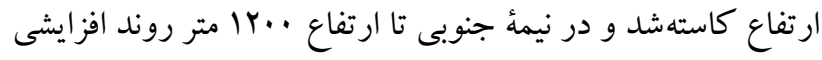
داشته و سيس همر اه با افزايش ارتفاع مجدداً كاسته شد (جدول Y). اختلاف معنىدارى در ميزان فعاليت آنزيم آسكورباتيراكسيداز در ميان و درون جمعيت مشاهده نشد ( جدول ب). نتايج ميزان يالاستيسيتى فيزيولوزيكى (PPI) نشان داد كه آنزيم يراكسيداز بيشترين ميزان بِاستيسيتى (V9D/•) را از خود نشان داد و آنزيم آسكوربات پيراكسيداز هم كمترين ميزان بِاستيسيتى (999/•) فيزيولوزيكى را از خود نشان داد. نتايج بهدست آمده نشان داد كه در هر سه آنزيم يراكسيداز، كاتالاز و آسكوربات براكسيداز نمونه هاى جمع آورىشده از نيمهُ شمالى و رشدكرده در سايه،

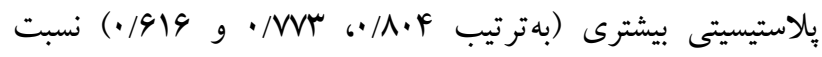
نمونه هاى جمع آورى شده از نيمهُ جنوبى دارند (جدول F).
در اين فرمول PPI و بلاستيسيتى آنزيم مورد نظر، حداكثر و حداقل مقدار آنزيم در ارتفاعات و جهات مختلف است. نتايتج نتايج تجزيه واريانس نشان داد كه فعاليت آنزيم :يراكسيداز اختلاف معنىدارى را در ميان و درون جمعيت دارد. همجنين اختلاف معنى دارى در ميز ان فعاليت آنزيم كاتالاز در ميان و درون جمعيت مشاهده شد. ياسخ درختهاى تحتمطالعه نسبت به تغييرات ارتفاعى يكسان نبود. فعاليت آنزيم يراكسيداز بركگهاى درختان راش روند افزايشى را در دو نيمةٔ تاج درخت نشان داد و اين افزايش بهنحوى بود كه فعاليت آنزيم در نيمهٔ شمالى تاج درختان بيشتر از نيمهُ جنوبى مشاهده شد (جدول Y ب، شكلهاى ا و Y). فعاليت آنزيم كاتالاز نيز با افزايش ارتفاع دجار تغييرات شد و همانند فعاليت آنزيمى براكسيداز، در نيمٔ شمالى بيشتر ار نيمٔ 


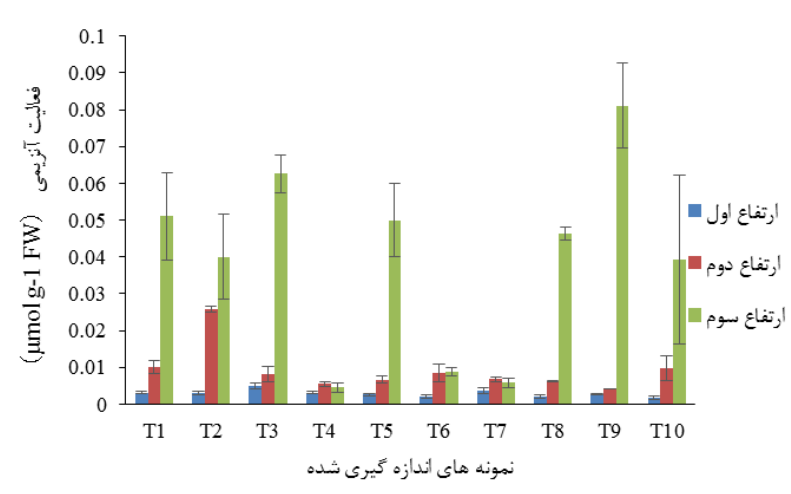

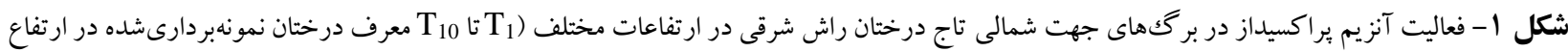

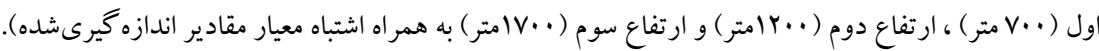

Fig. 1. Peroxidase enzyme activity in the northern direction leaves of the $F$. orientalis trees crown at different altitudes (T1 to T10 represents the trees sampled at the first altitude $(700 \mathrm{~m})$, the second altitude $(1200 \mathrm{~m})$ and the third altitude $(1700 \mathrm{~m})$, with the standard error of measured values).

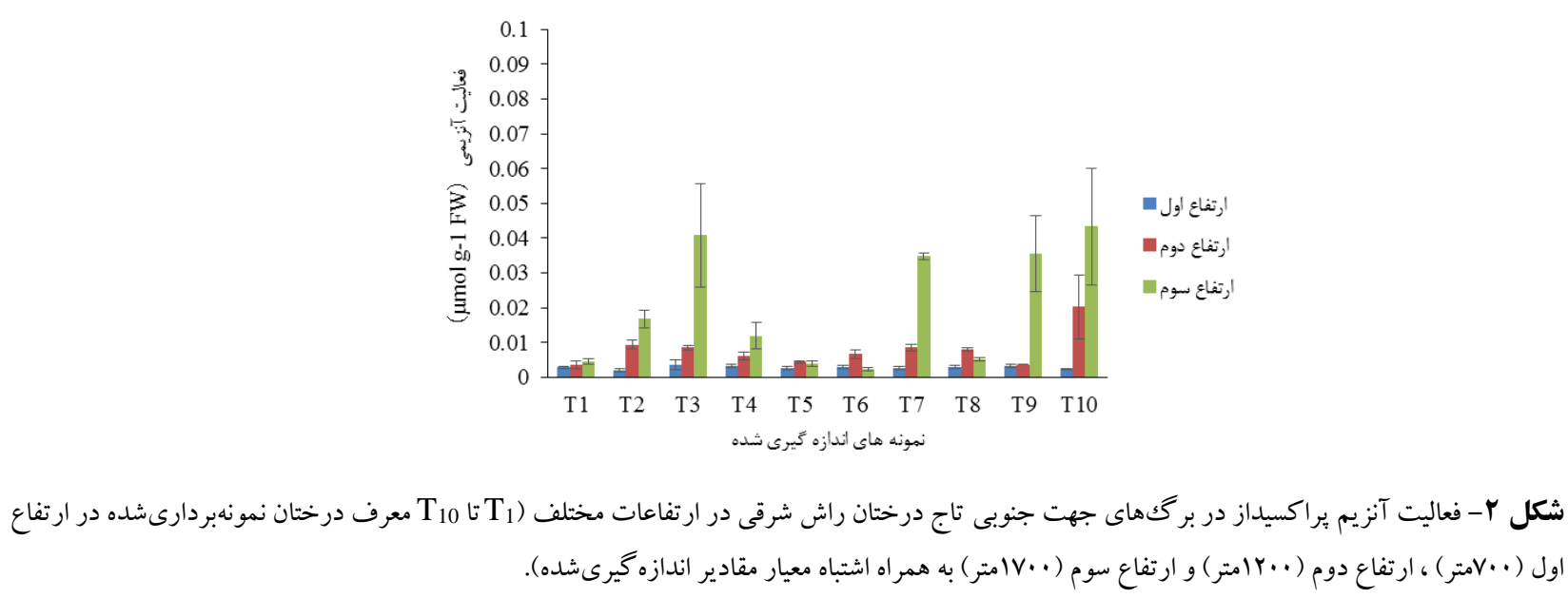

Fig. 2. Peroxidase enzyme activity in the Southern direction leaves of the F. orientalis trees crown at different altitudes (T1 to T10 represents the trees sampled at the first altitude $(700 \mathrm{~m})$, the second altitude $(1200 \mathrm{~m})$ and the third altitude $(1700 \mathrm{~m})$, with the standard error of measured values).

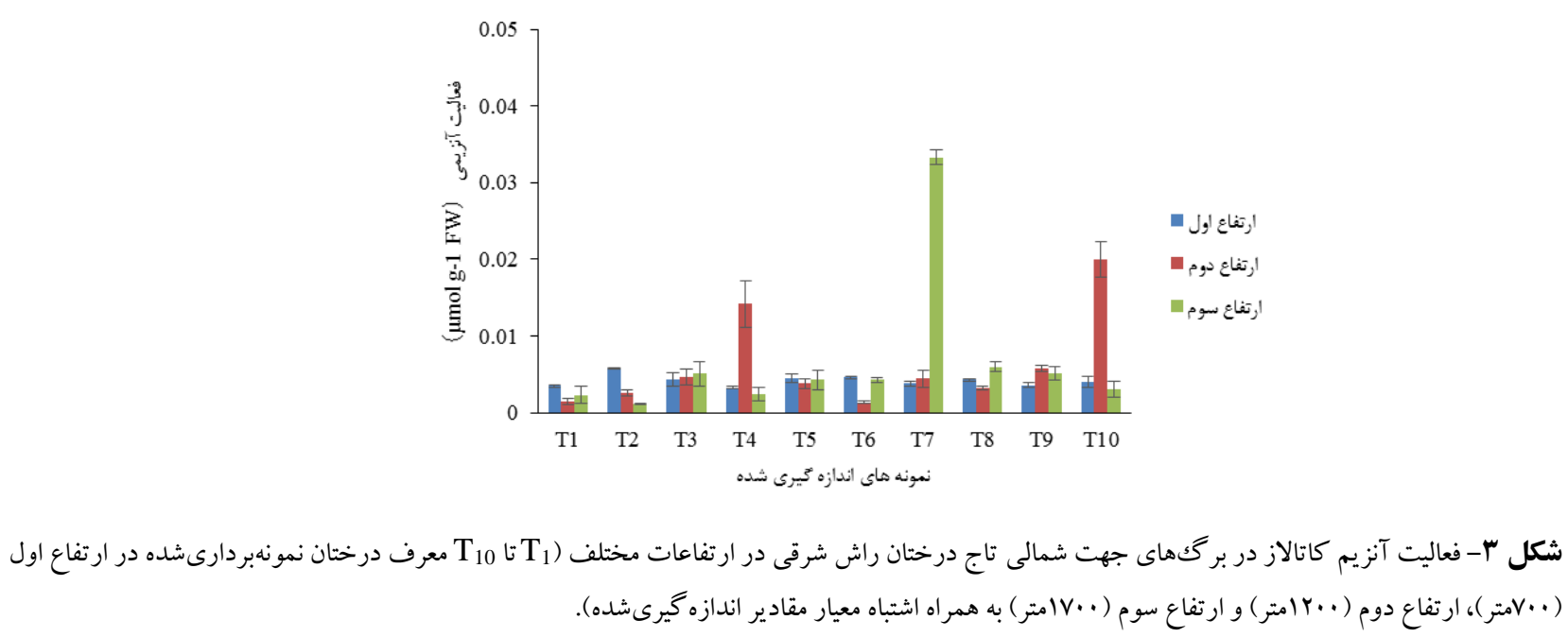

Fig. 3. Catalase enzyme activity in the northern direction leaves of the $F$. orientalis trees crown at different altitudes (T1 to T10 represents the trees sampled at the first altitude $(700 \mathrm{~m})$, the second altitude $(1200 \mathrm{~m})$ and the third altitude $(1700 \mathrm{~m})$, with the standard error of measured values). 
$100 / 1 \cdots$

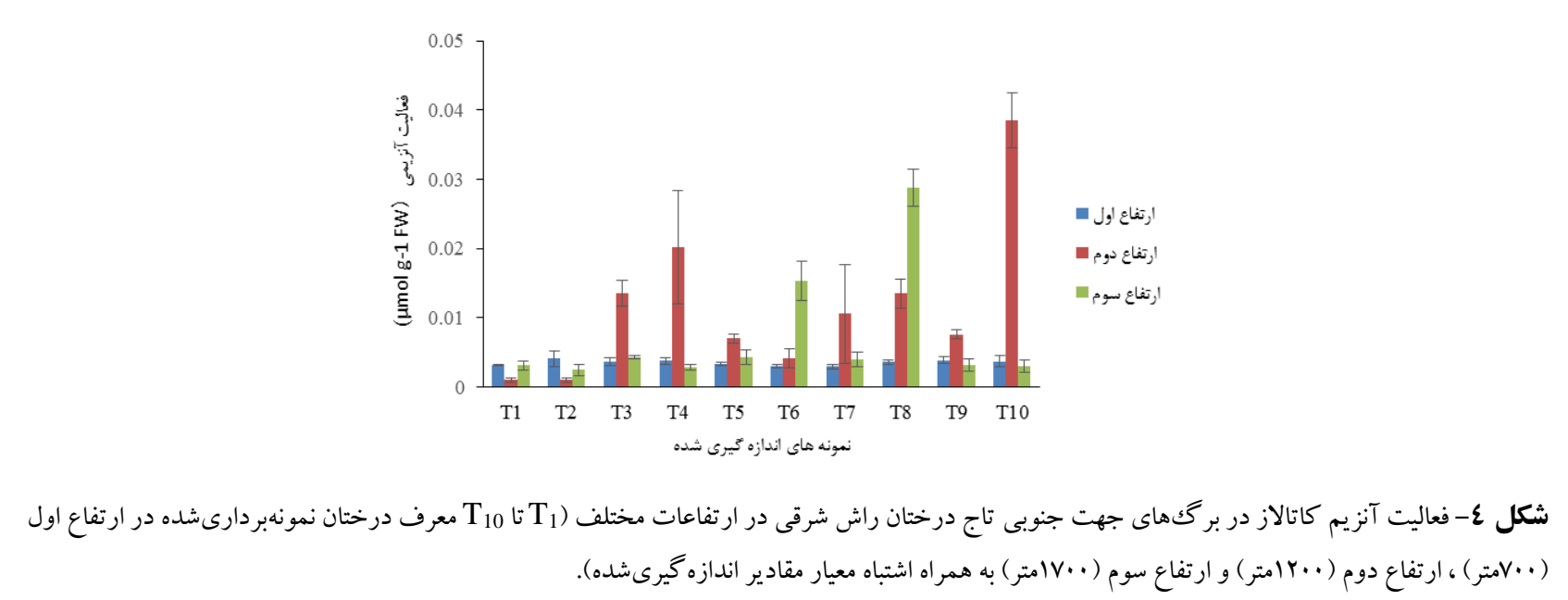

Fig. 4. Catalase enzyme activity in the Southern direction leaves of the $F$. orientalis trees crown at different altitudes (T1 to T10 represents the trees sampled at the first altitude $(700 \mathrm{~m})$, the second altitude $(1200 \mathrm{~m})$ and the third altitude $(1700 \mathrm{~m})$, with the standard error of measured values).

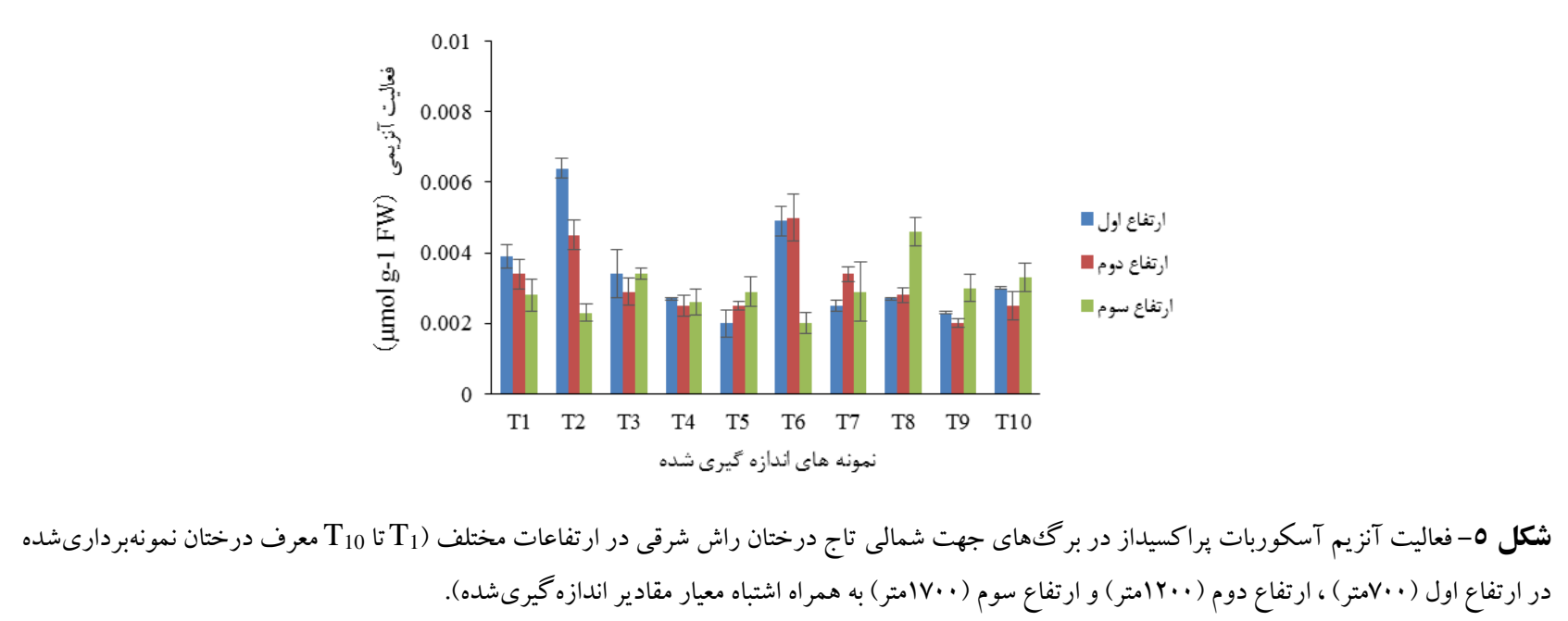

Fig. 5. Ascorbate peroxidase enzyme activity in the northern direction leaves of the $F$. orientalis trees crown at different altitudes (T1 to T10 represents the trees sampled at the first altitude $(700 \mathrm{~m})$, the second altitude $(1200 \mathrm{~m})$ and the third altitude $(1700 \mathrm{~m})$, with the standard error of measured values).

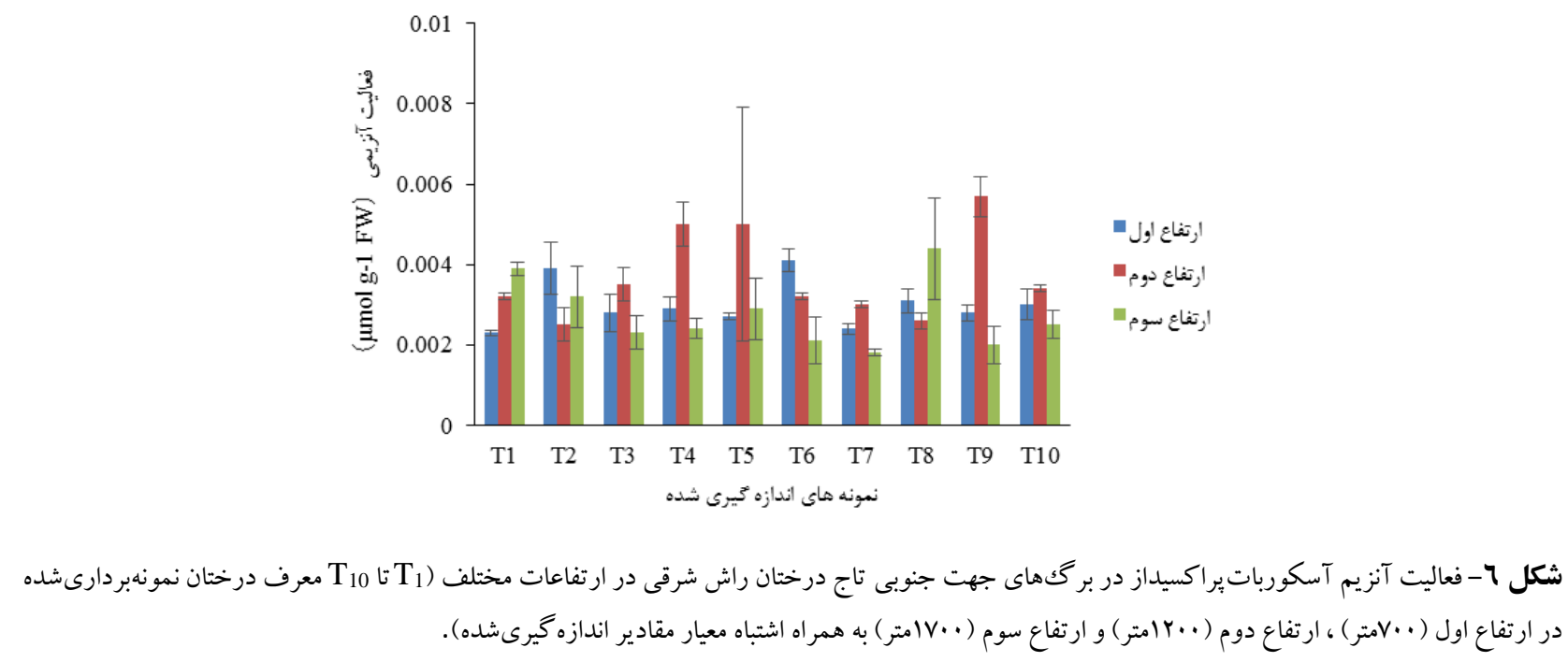

Fig. 6. Ascorbate peroxidase enzyme activity in the southern direction leaves of the $F$. orientalis trees crown at different altitudes (T1 to T10 represents the trees sampled at the first altitude $(700 \mathrm{~m})$, the second altitude $(1200 \mathrm{~m})$ and the third altitude $(1700 \mathrm{~m})$, with the standard error of measured values). 
جدول ع- ميزان پِلاستيسيتى فيز يولوزيكى (PPI) راش شرقى در ارتفاعات مختلف.

Table 4. Physiological plasticity (PPI) of F.orientalis at different altitudes.

\begin{tabular}{|c|c|c|c|c|c|}
\hline \multicolumn{3}{|c|}{ ميزان بلاستيسيتى (PPI) } & \multirow{2}{*}{$\begin{array}{l}\text { ارتفاع } \\
\text { (m) }\end{array}$} & \multirow{2}{*}{ جهت } & \multirow{2}{*}{ آنزيم } \\
\hline & & مقدار & & & \\
\hline \multirow{6}{*}{$\cdot / N 90$} & \multirow{3}{*}{$\cdot / A \cdot F$} & .19449 & $v_{n}$. & \multirow{3}{*}{ شمالى } & \multirow{6}{*}{ ير براكسيداز } \\
\hline & & • $/ A T V Y$ & $1 r .$. & & \\
\hline & &.$/ Q F F D$ & IV.. & & \\
\hline & \multirow{3}{*}{. VYY } &.$/ 4199$ & v.. & \multirow{3}{*}{ جنوبى } & \\
\hline & &.$/ 19191$ & $1 r .$. & & \\
\hline & & . /9q94 & IV.. & & \\
\hline \multirow{6}{*}{ - MFF } & \multirow{3}{*}{$\cdot / \mathrm{Vr}$} & $. / 4+1$ & $\mathrm{v} \cdot$. & \multirow{3}{*}{ شمالى } & \multirow{6}{*}{ كاتالاز } \\
\hline & &.$/ 94$ & ir.. & & \\
\hline & &.$/ 9999$ & IV.. & & \\
\hline & \multirow{3}{*}{. N19 } & - MYAY & $v^{\prime}$. & \multirow{3}{*}{ جنوبى } & \\
\hline & &.$/ Q V F$ & Ir. & & \\
\hline & &.$/ 914$ & iv.. & & \\
\hline \multirow{6}{*}{.$/ 499$} & \multirow{3}{*}{.$/ 919$} &.$/ 91 \mathrm{~V}$ & $v \cdot$. & \multirow{3}{*}{ 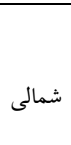 } & \multirow{6}{*}{ آسكوربات براكسيداز } \\
\hline & & $\cdot 19$ & $1 r$. & & \\
\hline & & .1090 & IV.. & & \\
\hline & \multirow{3}{*}{ - } & $\cdot / 4 r q$ & $v \cdot \cdot$ & \multirow{3}{*}{ جنوبى } & \\
\hline & & .1091 & $1 r .$. & & \\
\hline & & $\cdot / 09$ & IV.. & & \\
\hline
\end{tabular}

هاى محيطى حساس است و قادر است

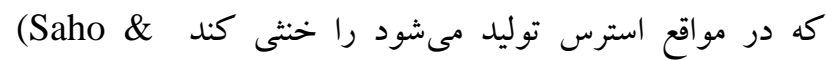
(1987; Sagisaka, 1985 Mishrah,) مانند كاهش رطوبت خاكى، كاهش بارندگى و افزايش خشكى و

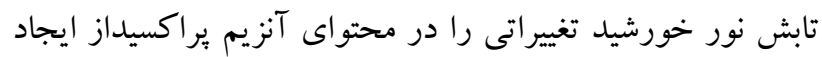

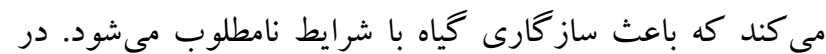

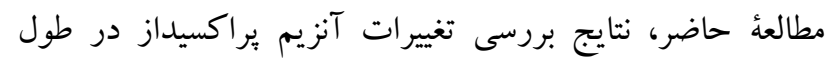

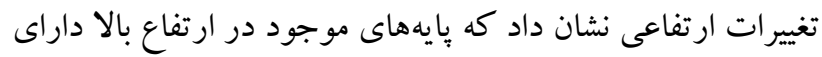

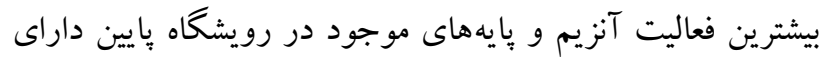

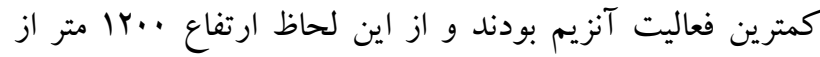

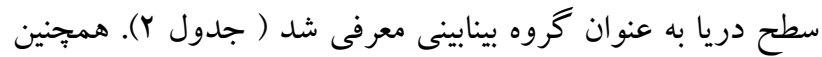

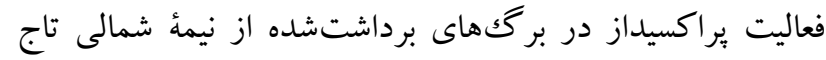

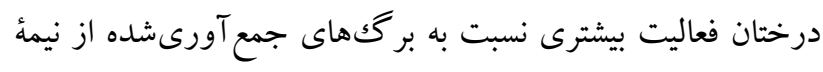

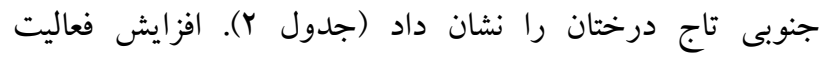
يراكسيداز باسخى از جانب گياه به افزايش ROSها است. آنزيم

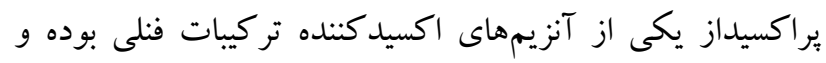

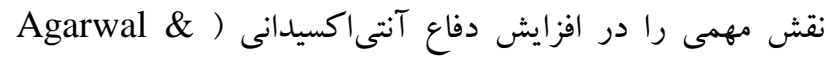
Pandey, 2004
يوشش گياهى در ارتفاعات بالاتر شامل گياهانى است كه با

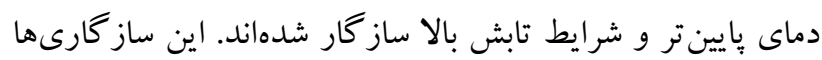

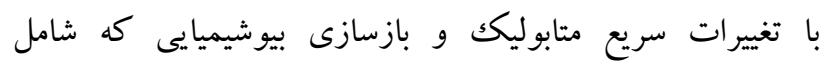
تر كيبات و آنزيمهاى آنتى اكسيدانى است، همر اه است ( Öncel et 1998 بيوشيميايى و فيزيولوزيكى مختلف براى انعطاف بذيرى در برابر

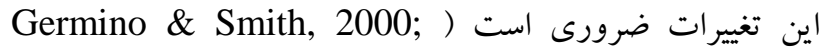
Streb et al., 1998; Wildi \& Lütz, 1996 همراه با افزايش ارتفاع، ميزان فعاليت آنزيمهاى يراكسيداز و كاتالاز روند افزايشى را نسبت به تغييرات ارتفاعى از خود نشان دادند. تحت شرايط عادى، سلولهاى گياهى قادر به حفظ تعادل بين توليد ROS و وبخش آنها هستند، اما تحت استرس محيطى سلولى طولانى مدت، ROS انباشته شده و به آسيب منجر مىشود.

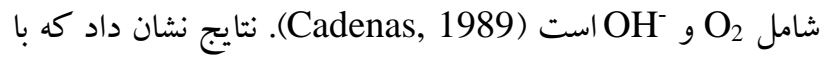
افزايش ارتفاع بر فعاليت آنزيم يراكسيداز افزوده مى شودد. آنزيم

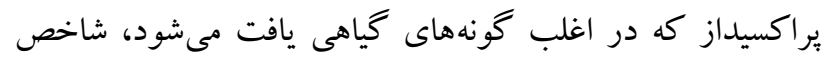

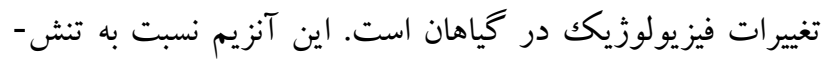


بنابراين، نتايج حاكى از تغييرات متابوليكى قابل توجه در بر گكهاى

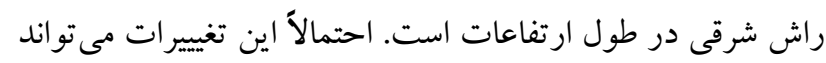

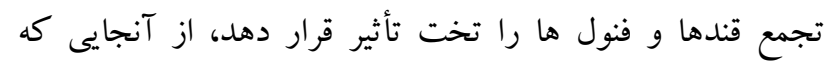
(2004) Schultz Allison مهمى در اين مسيرهاى سوختوساز دارند. نتايج نشان داد كه

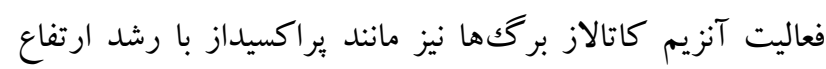

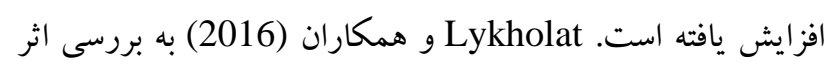

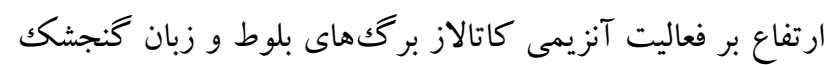

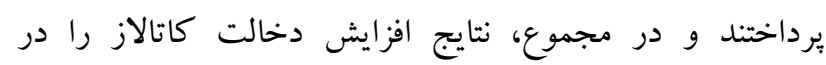

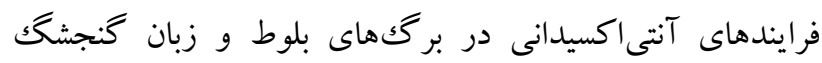

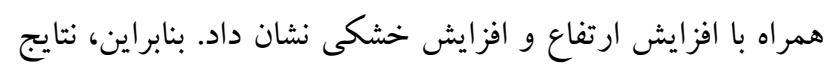
مطالعه حاضر با نتايج تحقيق Lykholat و همكاران (2016) و و Mhamdi

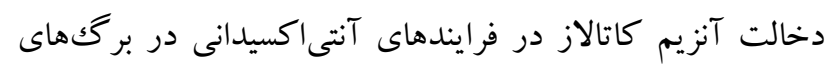

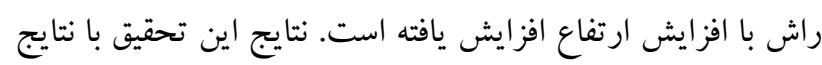
Queval's

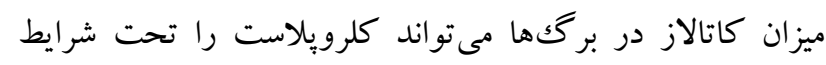
تنشهايى كه توليدكنندة اصلى كونه هاى اكسيزن فعال هستند محافظت كند (Foyer \& Shigeoka, 2011). همجينين براساس

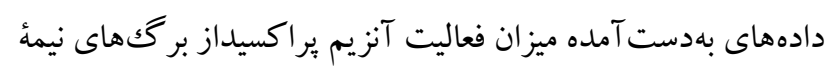

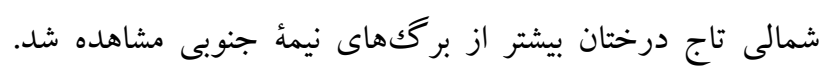

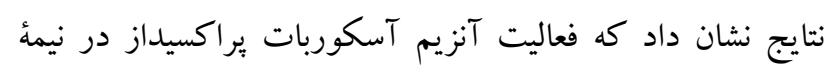

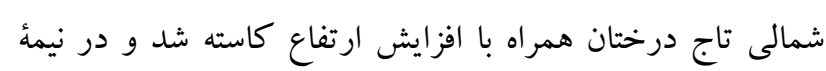

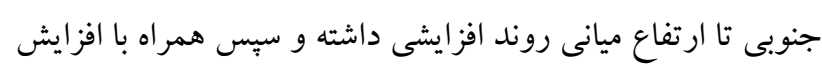

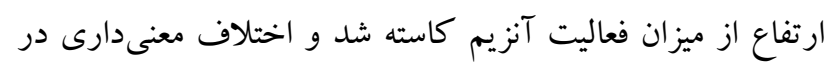
فعاليت آنزيم آسكوربات براكسيداز در ميان جمعيت و و درون

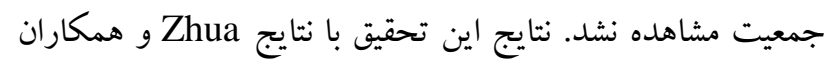
(2010) همسو است. Zhua و همكاران (2010) با مطالعة تهئ ساز گارى اكوفيزيولوزى Calligonum roborovskii در هـاسخ

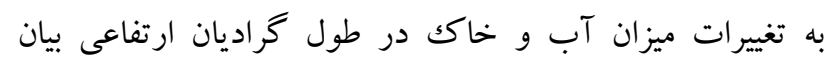

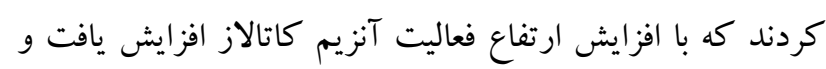

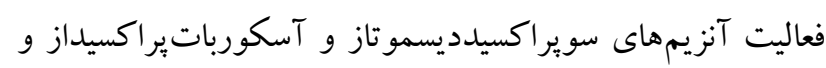
يراكسيداز در ارتفاع اول بيشتر از ارتفاع دوم و سوم بود و و خنين

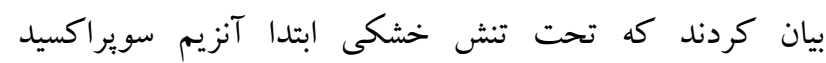

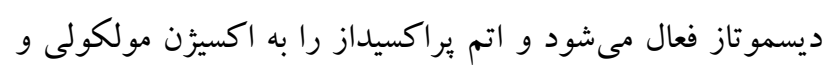

شورى و تنش فلز سنخين دارد (Aslam et al., 2011). Lykholat كنجشك (Fraxinus excelsior L.) و و بلوط ( Quercus تغيير در ميزان فعاليت آنزيم يراكسيداز را در طول (robur L.

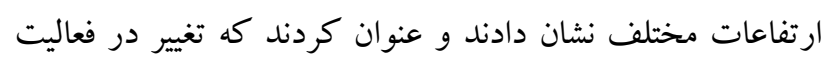

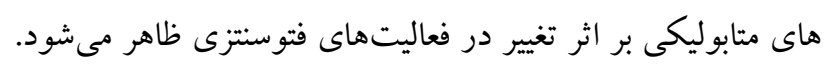

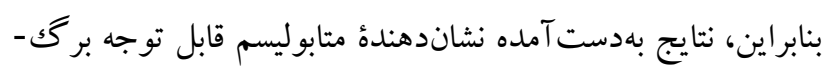

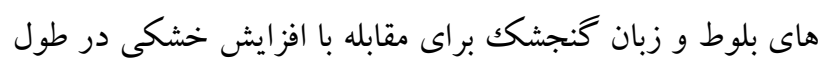

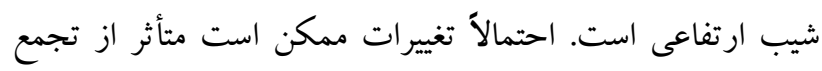

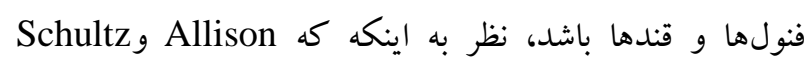

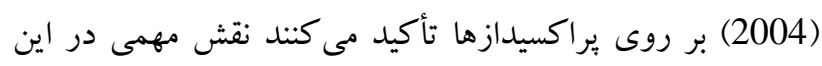

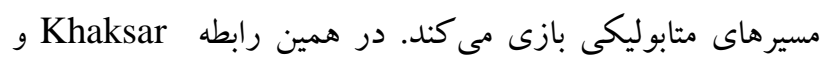
Acer velutinum (2015) با بررسى گمونه افرايلت

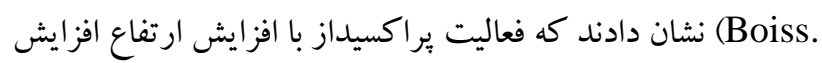

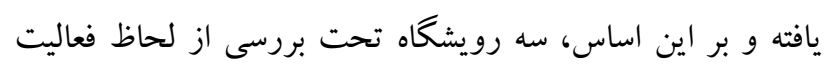

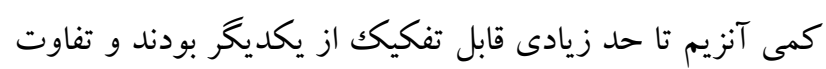

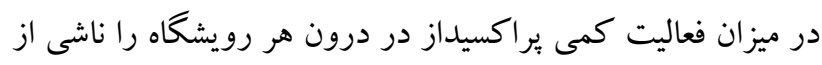

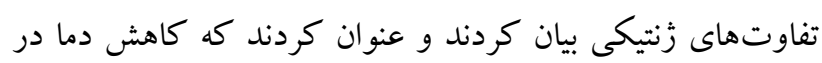
ارتفاعات بالاتر باعث افزايش فعاليت كمى و كيدى كيفى آنزيم يراكسيداز براى توليد ليكنين شده است. Parhizkar و همكاران

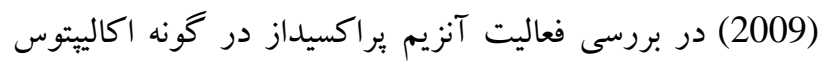
نشان داد كه تغييرات فعاليت (Eucalyptus viminalis Labill) يراكسيداز در بِايههاى مختلف متفاوت بوده است. نتايج بهطور

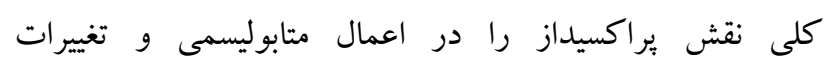
فيزيولوزيكك E. viminalis نشان داد و افزايش فعاليت آنزيم يراكسيداز طى فصل هاى سرد سال را دليلى بر نقش اين آنزيم در مقابله با آسيبهاى ناشى از سرما (Parhizkar et al., 2009) و دليلى براى جبران ميزان كل فعاليت آنزيمها در دماى بايين اظهار

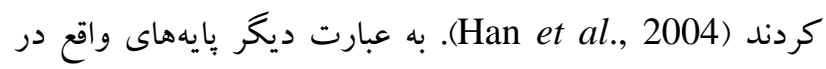
ارتفاعات بالاتر براى مقابله با تنشهاى محيطى از جمله سرماى بله بله

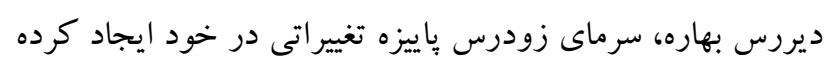

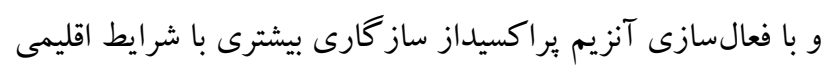

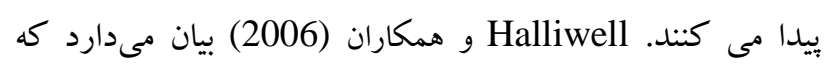
عمل كرد آنزيم يراكسيداز جوامع گياهى با حذف بر براكسيد اكسيزن

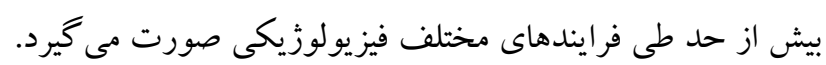


را مى توان براى شناسايى وِايه هاى مقاوم نسبت به تنشهاى محيطى

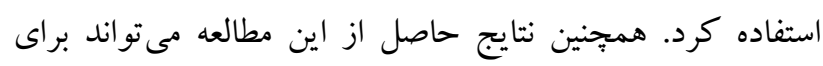
ارزيابى انطباقى گونهاى جوبى نسبت به تغييرات آب وهوايى مفيد واقع شود.

\section{سياسگز ارى}

نغارند گان از مسئولين آزمايشگاه دانشكده كشاورزى دانشگاه كيلان بخاطر فراهم كردن امكانات و همكارى در انجام اين تحقيق

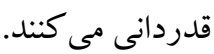

\section{REFERENCE}

Allison, S.D. and Schultz, J.C. 2004. Differential activity of peroxidase isozymes in response to wounding, gypsy moth, and plant hormones in Northern red oak (Quercus rubra L.). - Chem. Ecol. 30: 1363-1379.

Agarwal, S. and Pandey, V. 2004. Antioxidant enzyme responses to $\mathrm{NaCl}$ stress in Cassia angustifolia. Biol. Plant 48: 555-560.

Araujo, W.L., Dias, P.C. and Moraes, G.A. 2008. Limitations to photosynthesis in coffee leaves from different canopy positions. - Plant. Physio. Bio. 46: 884-890

Aslam, R., Bostan, N., Nabgha-e-Amen, M.M. and Safdar, W. 2011. A critical review on halophytes: salt tolerant plants. - Med. Plants. Res. 5: 7108-7118.

Babaei, F., Jalali, S.A. and Azadfar, D. 2012. Investigation of genetic variation in Zelkova carpinifolia by use of leaf peroxidase isozyme in three lowland habitats in north of Iran. - Wood. Forest. Sci. Tech. 19: 121-133.

Babaei, F., Jalali, S.G., Sohrabi, H. and Shirvany, A. 2016. Physiological responses of seedlings of different Quercus castaneifolia C.A. Mey. Provenances to heterogeneous light environments. Forest Sci. 62: 485-491.

Bayramzadeh, V. 2011. Stomatal characteristics of Fagus orientalis Lipsky. in geographically separated locations in the Caspian Forests of Northern Iran. Environ. Sci. 5: 836-840.

Beauchamp, C. and Fridovich, I. 1971. Superoxide dismutase: improved assays and an assay applicable to acrylamide gels. - Anal. Biochem. 44: 276-87.

Canche, B. and Maehly, A.C. 1955. Assay of catalase and peroxidases. - Methods Enzymol. 2: 764-775.

Carpenter, S.B. and Smith, N.D. 1981. A comparative studies of leaf thickness among Southern Appalachian hardwoods. - Botany 59: 1393-1396.

Cadenas, E. 1989. Biochemistry of Oxygen Toxicity. Annu. Rev. Biochem. 58: 79-110.

Cesar, A.R., Antunes, M.T. and Vidal, P.G. 2010. Método do estudo de caso em pesquisas da área de contabilidade: uma comparação do seu rigor metodológico em publicações nacionais e internacionais. - Revista de Informação Contábil. 4: 42-64.
تبديل مى كند و سيس آنزيمهاى براكسيداز و آسكوربات يراكسيداز در ارتفاع اول و دوم ممكن است بهدليل انباشت روشنايى باشد. افزايش ارتفاع و تغيير در شرايط محيطى باعث افزايش استرس اكسيداتيو در ارتفاعات بالاتر و تجمع كونهاى

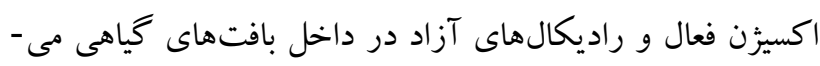
شود. تحت اين شرايط، گياه سيستم دفاعى خود را بهمنظور بالابردن مقاومت در برابر تنشها افزايش مىدهد. بنابراين، يراكسيداز و كاتالاز برك داراى فعاليت فيزيولوزيكك بيشترى نسبت به افزايش تركيبات اكسيثن فعال با افزايش ارتفاع، به خصوص ارتفاع بالاتر از · .با متر بود. مقادير ميانگين بِاستيسيتى فيزيولوزيكى در آنزيمهاى تحت بررسى نشان داد كه آنزيمهاى براكسيدار، كاتالاز و آسكوربات براكسيداز بالاترين ميزان تغييرات

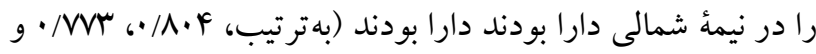
1919 •). موقعيت قرارگيرى بر ₹كها روى تاج درختان و همجنين تفاوت در ميزان نور دريافتى نيمهُ شمالى و جنوبى تاج درختان مى تواند از عوامل تغيير در عمل كرد آنزيمها باشند. همجينين فعاليت بيشتر آنزيمها در نيمهُ شمالى نشان مىدهد كه سايه بهطور مثبتى بر ياسخ هاى فيزيولوزيكى به تغييرات محيطى (آنزيمهاى آنتىاكسيدانى) تأثير مى گذارد. مطالعات زيادى به قابليت سازش يذيرى فيزيولوزيكى گونه هاى گياهى به شرايط مختلف نورى برداختهاند Han et al., 2004; Matos et al., 2009; Araujo et al., ) 2008). علاوه بر شرايط نورى، عوامل ديخرى مانند دما و استرس آبى نيز مىتواند بر روى عمل كرد برگك تأثير گذار باشد ( Carp enter \& Smith, 1981 پِاستيسيتى فيزيولوزيكى در نيمهُ شمالى و جنوبى تاج درختان

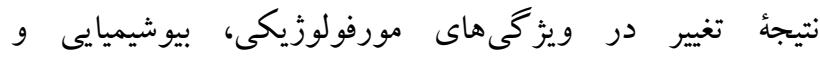
فيزيولوزيكى همراه با تغييرات ارتفاعى است. در اين مطالعه تغييرات عمل كرد برگك درختان راش شرقى در امتداد گراديان ارتفاعى تحت بررسى قرار گرفت. نتايج مطالعهُ حاضر حساسيت برگك درختان راش را نسبت به تفاوتهاى محيطى در مقياس كوجّك همراه با افزايش ارتفاع نشان مىدهد. علاوه براين، سازو كارهاى بيوشيميايى كه شامل اجزاى دفاعى آنتىاكسيدانى هستند نقش مؤثرى در تطبيق پِاسخ گياهان نسبت به تنشهاى اكسيداتيو در ارتفاعات بالا دارند. نتايج بهدست آمده از اين مطالعه 
Espahbodi, K. 2005. Genetic variation and effects of genotype and environment on the establishment and growth mountain ash (Sorbus torminalis). - Ph.D Thesis, Tarbiate Modarres University. pp 74.

Foyer, C.H. and Shigeoka, S. 2011. Understanding oxidative stress and antioxidant functions to enhance photosynthesis. - Plant Physiol. 155: 93-100.

Germino, M.J. and Smith, W.K. 2000. High resistance to low temperature photoinhibition in two alpine, snowbank species. - Physiol. Plantarum 110: 89-95.

Gill, S.S. and Tuteja, N. 2010. Reactive oxygen species and antioxidant machinery in abiotic stress tolerance in crop plants. - Plant. Physio. Bio. 48: 909-930.

Halliwell, B. 2006. Reactive species and antioxidants. Redox biology is a fundamental theme in aerobic life. - Plant Physiol. 141: 312-322.

Han, Q., Katahata, S., Kakubari, Y. and Mukai, Y. 2004. Seasonal changes in the xanthophyll cycle and antioxidants in sun-exposed and shaded parts of the crown of Cryptomeria japonica in relation to rhodoxanthin accumulation during cold acclimation. Tree Physiol. 24: 609-616.

Hatziskakis, S., Tsiripidis, I. and Papageogioui, A.C. 2011. Leaf morphological variation in beech (Fagus sylvatica L.) populations in Greece and its relation to their post-glacial origin. - Linnaean Society 165: 422436.

Khaksar, R., Aldaghi, M., Salimi, A. and Espahbodi, K. 2015. Investigation on qualitative and quantitative changes of peroxidase isozyme in maple (Acer velutinum) at different altitudes of Mazandaran forests. - Range. Forest. Plant. Breed Gen. Res. 23: 203-214.

Karner, C., Farquhar, G.D. and Roksandic, Z. 1988. A global survey of carbon isotope discrimination in plants from high altitude. - Oecologia 74: 623-632.

Keles, Y. and Everest, A. 2008. Relation to altitude adaptation and antioxidant defense system in five shrubs and trees species from middle Taurus Mountains. - Natural. Eng. Sci 2: 45-49.

Lykholat, Y., Khromyk, N., Ivanko, I., Kovalenko, I., Shupranova, L. and Kharytonov, V.M. 2016. Metabolic responses of steppe forest trees to Altirude Associated local environmental changes. - Agri. For. 62: 163-171.

Mhamdi, A., Queval, G., Chaouch, S., Vanderauwera, S., Van Breusegem, F. and Noctor, G. 2010. Catalase function in plants: a focus on Arabidopsis mutants as stress-mimic model. - Environ. Experi. Bot. 61: 41974220

Matos, F. S., Wolfgramm, R., Goncalves, F.V., Cavatte, P.C., Ventrella, M.C. and DaMatta, F.M. 2009. Phenotypic plasticity in response to light in the coffee tree. - Environ. Exper. Bot. 67: 421-427.

Nakano, Y. and Asada, K. 1981. Hydrogen peroxide is scavenged by ascorbate specific peroxidase in spinach chloroplasts. - Plant. Cell. Physiol. 22: 867-880.

Öncel, L., Yurdakulol, E., Keleş, Y., Kurt, L. and Yıldız, A. 2004. Role of antioxidant defense system and biochemical adaptation on stress tolerance of high mountain and steppe plants. - Acta Oecologica 26: 211-218.

Parhizkar, P., Korori, S.A., Moraghebi, F., Teimouri, M., Torabian, Y. and Manouchehri, N. 2009. Seasonal alteration of peroxidase in branch and leaves of Eucalyptus viminalis Labill. - For. Pop. Res. 16: 368377.

Polle, A. 1996. Mehler Reaction: Friend or Foe in Photosynthesis? - Bot. Acta. 109: 84-89.

Queval, G., Issakidis-Bourguet, E., Hoeberichts, F.A., Vandorpe, M., Gakiere, B, Vanacker, H., MiginiacMaslow, M., Van Breusegem, F. and Noctor, G. 2007. Conditional oxidative stress responses in the Arabidopsis photorespiratory mutant cat 2 demonstrate that redox state is a key modulator of daylengthdependent gene expression, and define photoperiod as a crucial factor in the regulation of $\mathrm{H}_{2} \mathrm{O}_{2}$-induced cell death. - Plant J. 52: 640-657.

Qipeng, H., Guo, ZH. and Li, CY. 2008. Advance at phenotypic plasticity in plant responses to abiotic factors. - Sci. Silvae. Sinicae 44: 136-142.

Raeisi, S., Jalali, S.G. and Espahbodi, K. 2011. An investigation of genetic variation of (Quercus castaneafolia C.A.Meyer) in Neka and Noor forest of Mazandaran using peroxidase activities. - Tax. and Bio. 2: 11-22.

Rundel, P.W., Gibson, C.A., Sharifi, M.R. and Esler, K.J. 1998. Morphological and physiological components of adaptations to light environments in neotropical Heliconia (Heliconiaceae). - J. Trop. Ecol. 14: 789801.

Sagisaka, S. 1985. Injuries of cold acclimatized polar twigs resulting from enzyme inactivation and substrate during frozen and ambient for a long period. - Plant Cell Physiol. 28: 1135-1145.

Saho, A.C. and Mishra, D. 1987. Changes in some enzyme activities during excised rice leaf senescence under NaCl-stress. - Bio. Physio. 182: 501-505.

Sofo, A., Dichio, B., Xiloyannis, C. and Masia, A. 2005. Antioxidant defenses in olive trees during drought stress: changes in activity of some antioxidant enzymes. - Func. Plant. Bio. 32: 45-53.

Streb, P., Shang, W., Feierabend, J. and Bligny, R. 1998. Divergent strategies of photo protection in highmountain plants. - Planta 207: 313-324.

Zhua, J.T., Lia, X.Y., Zhanga, X.M., Zenga, F.J., Lina, L.S., Yanga, S.G. Guiaand, D.W. and Wang, H. 2010. Ecophysiological adaptation of Calligonum roborovskii to decreasing soil water content along an altitudinal gradient in the Kunlun Mountains, Central Asia. - Plant Physiol. 57: 826-832.

Wildi, B. and Lütz, C. 1996. Antioxidant composition of selected high alpine plant species from different altitudes Plant. - Cell. Environ. 19: 138-146.

Yamasaki, H., Sakihama, Y. and Ikehara, N. 1997. Flavonoid-peroxidase reaction as a detoxification mechanism of plant cells against $\mathrm{H}_{2} \mathrm{O}_{2}$. - Plant. Physiol. 115: 1405-1412.

Zolfaghari, R., Hosseini. S.M. and Korori, S.A. 2010. Relationship between peroxidase and catalase with metabolism and environmental factors in Beech 
(Fagus orientalis Lipsky in three different elevations.

- Environ. Sci. 1: 243-252.

$$
* * * * *
$$

\section{How to cite this article:}

Mohebi Bijarpasi, M., Rostami Shahraji. T. and Samizadeh Lahiji, H.A. 2018. Study of antioxidant enzymes activity of Fagus orientalis Lipsky to environmental changes along altitude gradient (case study: Guilan forests, Masal). - Nova Biologica Rep. 2018: 95-105.

محبى بيجاريسى، م.، رستمى شاهراجى، ت. و سميعزاده لاهيجى، ح.ا.

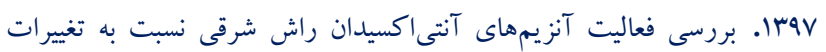
محيطى در طول گراديان ارتفاعى (مطالعهى موردى: جنغل هاى گيلان، ماسال).

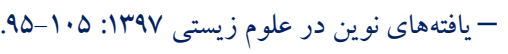

